
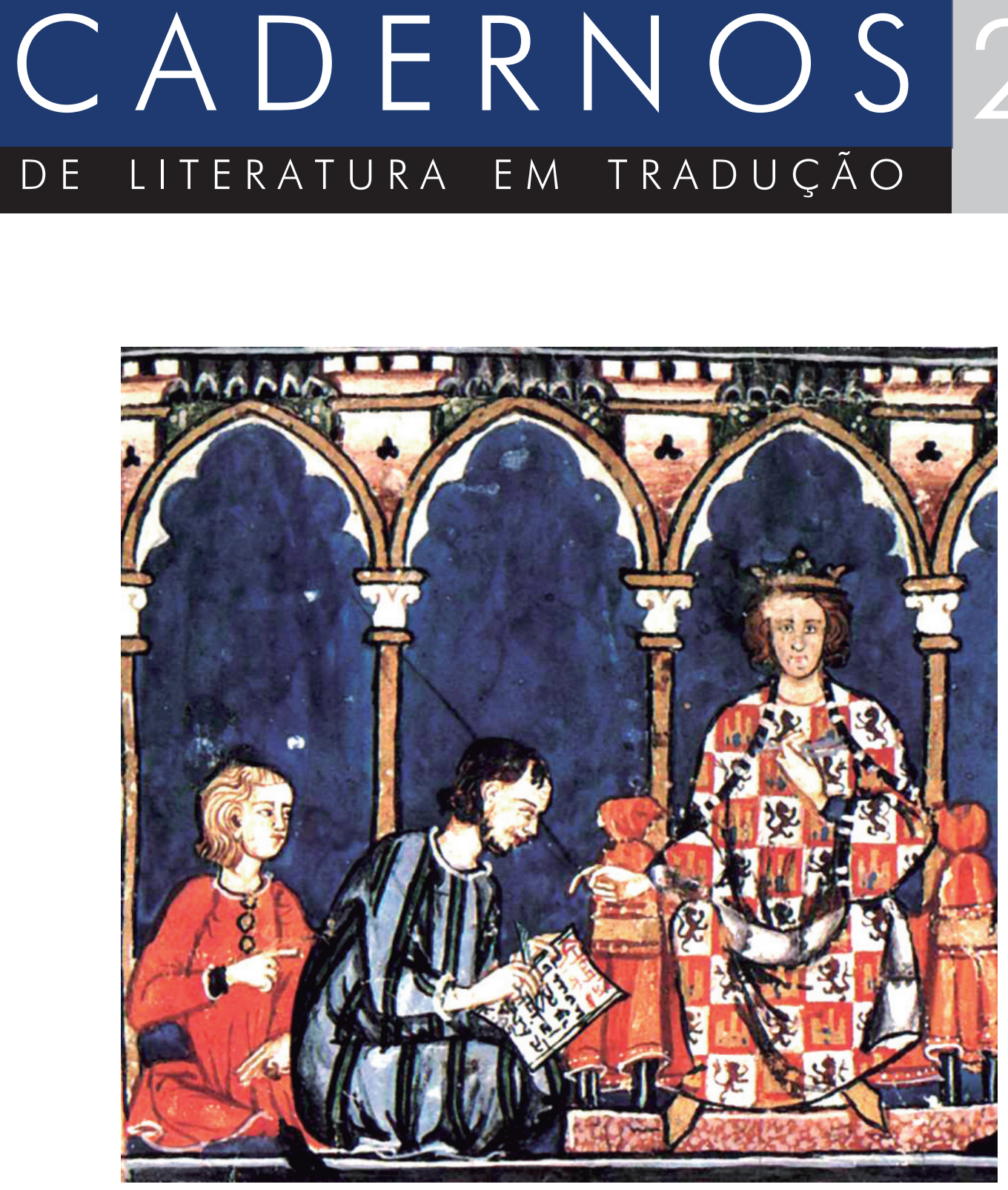

Tradutores da chamada Escola de Toledo com Afonso $X$ de Castela 


\title{
O vazio de Socorro Venegas
}

\author{
Nylcéa Thereza de Siqueira Pedra
}

Resumo: Pode uma mãe não sentir amor por seu filho recém-nascido? Esta é a pergunta que emerge - e desconcerta - na leitura do conto "O vazio", de Socorro Venegas. A solidão de uma mãe em puerpério, a ausência da compreensão daqueles que estão à sua volta e a descoberta de que existe um caminho a ser percorrido até o encontro entre mãe e filho são os motes de um texto transgressor e avassalador. Na tradução apresentada, a escolha pelo "vazio" se faz de modo a reverberar a série de ausências sentidas pela personagem.

Palavras-chave: Socorro Venegas, maternidade, escritora latino-americana, tradução.

Resumen: ¿Sería posible una madre no sentir amor por su hijo recién nacido? Esta es la pregunta que emerge - y desconcierta - en la lectura del cuento "El hueco", de Socorro Venegas. La soledad de una madre en puerperio, la ausencia de la comprensión de los que forman parte de su vida y el descubrimiento de que existe un camino a recogerse hasta el encuentro entre madre e hijo son los motivos de un texto transgresor y avasallador. En la traducción presentada, la elección por "vazio" se hace de modo a reverberar la serie de ausencias sentidas por el personaje.

Palabras-clave: Socorro Venegas, maternidad, escritora latinoamericana, traducción.

Nascida em San Luis Potosí (México) em 1972, Socorro Venegas divide o seu trabalho de escrita com a função de editora, tendo trabalhado no Fondo de Cultura Económica do México e atualmente na Universidade Nacional do México. Entre a sua produção literária, ainda inédita no Brasil, destaca-se a escrita de romances - La noche será negra y blanca (2009) e Vestido de novia (2014) - e contos - La risa de las azucenas (1997), La muerte más blanca (2000) e Todas las Islas (2002).

O seu último livro La memoria donde ardía, foi publicado em 2019. Composto por dezenove contos curtos, cuja concisão aponta para um tratamento preciso e 
rigoroso da palavra, versam sobre temas como a família, a perda e a maternidade. Não se tratam de histórias felizes ou de encontros, mas relatos de sobreviventes e suas cicatrizes. A dor narrada já não é a dor pulsante da ferida, mas a que se faz lembrar nos dias frios, no incômodo que a cicatriz evoca. Se há uma esperança, apesar da morte, do abandono, do incompreensível, ela reside na certeza de que é preciso seguir, olhando a vida de frente porque são as marcas que nos constituem.

E é nesse encarar a vida de frente que a autora se propõe a tratar de temas bastante sensíveis como o do conto aqui apresentado em tradução. Abandonando uma abordagem mais romantizada do tema, "O vazio" se aproxima da maternidade desde o viés dissidente, dando espaço e voz a uma mãe que não consegue estabelecer vínculo afetivo com o filho recém-nascido. Perdida de si mesma, memória do que era, sente o vazio de não saber quem é. Perambulando pela casa, tratada como doente, a construção da possível aproximação da criança também é interditada pela presença do pai que, se à primeira vista parece reivindicar para si o cuidado do filho, convida a pensar como no seu exercício de poder também usurpa da mãe o seu lugar. Não casualmente, o título do livro, verso de um soneto do poeta Francisco de Quevedo, nos conduz à uma possível chave de leitura para o conto. O "amor constante mais além da morte" acompanha a protagonista no seu sono-travessia.

No que tange à prática do exercício tradutório, o cuidado foi manter as frases breves e cortantes da autora, bem como respeitar as suas escolhas lexicais de modo a reconstruir a poeticidade do texto original. Embora não tenha sido difícil fazer escolhas, uma delas nos parece interessante justificar. Diz respeito ao substantivo "hueco", que aparece três vezes no texto, além de um registro de “oquedad". Poderíamos ter optado pelo correspondente mais direto em português - "oco", sem nada por dentro - mas entendemos que a escolha pelos substantivo "vazio" representa de maneira mais plena não apenas o "nada interior", registrado no ventre sem o filho, mas também o vazio existencial vivido pela personagem, que repercute, inclusive, na sua presença não presente na própria casa. O estado de quem nada contém é o retrato da mãe que precisa passar pela escuridão para encontrar uma sala quase vazia, com um tapete branco, na qual o seu filho the espera. 


\section{El hueco}

Socorro Venegas

Para Antonio Ramos Revillas

Dirijo mis pasos hacia la habitación del niño. No consigo llamarlo "hijo". La puerta se abre suavemente, la cuna es iluminada por la luz tenue de una lámpara. A un costado, en un futón, su padre duerme agotado. Es un cuadro desolador. ¿En dónde está la madre de esas dos criaturas? Me llevo las manos al vientre: un hueco, ahí donde el pequeño creció hasta el día del alumbramiento. Sí, el fantasma del dolor, eso que me impide dormir.

En la noche más honda, la del insomne, me levanto a caminar por la casa. Parecería sonámbula, pero sé que no lo soy. Veo los rincones y tengo ganas de llorar. No se me ocurre por qué.

Busco, he buscado en mis manos las sorpresas de una chistera. Nada.

Cambia de lugar mi fe. Mi brújula errante, esa pequeña fe.

Me despertó su llanto desconsolado, fui a verlo y me quedé acodada en el barandal de la cuna, observé atenta sus rasgos, tan indefinidos, ¿qué lo hacía mío?, ¿cuál inobjetable parecido? Sentía el impulso de cargarlo pero no hubiera sido una actuación genuina, sino un arrebato, un acto dictado más por la impaciencia, por el fastidio de escuchar los berridos, que un acto de amor. Entonces llegó él, y como yo no hacía nada por consolar al crío, me llamó "monstruo".

Estoy sola en esta incomprensible espera de un acto de amor. Mío. Mientras el niño lloraba, su padre, con el rostro incendiado, lo sacó de la cuna. Es tan pequeño que lo sostuvo con un brazo, con el otro me empujó.

Yo no quería parirlo. Me gustaba sentirlo moviéndose, un contorsionista infinito. Soñaba que en mí se gestaba un navegante, un vadeador de abismos. Solía sentarme a contemplar el jardín y el comprendía ese momento de paz, se quedaba quieto para convertirse apenas en una vibración, en un presentimiento. Llegué a creer que sería así siempre. ¿Es por eso que no entiendo lo sucedido? El ajetreo grosero del hospital, el parto, las visitas, las flores.

El hueco en que me convertí.

Aún la leche escapa de mis pezones, la succiono y luego la tiro en el lavabo. "No sirve", le recuerdo a él cuando me mira con reproche. Trato de disculparme porque soy una oquedad innecesaria en esta nueva vida que ya organizó: prepara biberones, cambia pañales, baña a la criatura. Se ocupa por entero. No se suponía que las cosas resultarían 
así. "Deja de mirar, solo sabes eso, ¡mirar!”, grita, mientras oculta en su regazo el estrecho cuerpo de mi angustia, ese niño. Soy una desconocida bajo su techo.

La desconocida solo puede limpiarse a sí misma y extraer la leche, un alimento venenoso. El doctor lo dijo, después de que el pequeño vomitara varias veces: "Su leche no es buena para el bebé". Dio la noticia mientras la enfermera se empeñaba en que el niño chupara mis senos. Súbitamente liberada, lo aparté y me di vuelta en la cama. Me dormí.

Su padre no permite que me acerque a mirarlos. Ese lado de la casa es, ya, territorio hostil. Hay una sirvienta que trae a mi cuarto la comida tres veces al día. Comida de enfermo: cosas blandas, incoloras. Le habrán contado alguna mentira para justificarme. Estoy casi segura de que echan algo en los alimentos, después de probarlos caigo en un sueño hondo, pero no de inmediato. En el descenso percibo cómo los familiares pasan de largo frente a mi puerta, los oigo saludar al padre, jugar con el niño, entregar los regalos, murmurar sobre mi "estado". "Medidas necesarias, obligarla...".

A veces no como y desde la ventana los veo alejarse, miran de reojo, saben que estoy aquí, me evitan. Murmuran entre sí. Han dicho algo, han decidido algo. Me acuesto de nuevo, cierro los ojos, quiero parecer dormida, ¿para engañar a quién? El fingimiento trae un efecto inesperado, de algún modo llega el letargo, y después, el sueño.

No sé cuánto tiempo he dormido. Esta vez me despierta la risa del niño. Me cuesta reconocer las paredes, el techo, la casa. Unos instantes me quedo paralizada en la cama. Es un sonido precioso. Continúa riéndose. Pero ¿una criatura tan pequeña puede reír así? Pongo los pies sobre el suelo y siento un cosquilleo frío que me arranca una sonrisa. Talvez gélida, pero auténtica. Salgo intrigada de mi cuarto, la risa continúa. Sigo el rastro de esa dicha.

La casa parece desierta. Tampoco veo a la sirvienta, siempre apostada y espiándome. En el centro de la habitación está el niño, solo, sentado sobre una alfombra blanca; se embadurna una crema para la piel. Tiene los brazos y las piernas cubiertos de color blanco. Un vértigo me orilla, me detengo del dintel. ¿Cuánto tiempo ha pasado? Ya puede sentarse sin que el peso de su cuerpo lo gane. Ha crecido. Y también está solo. Vuelve a reírse y en medio a su travesura dirige el rostro hacia donde estoy, veo un diente nuevo en esa carcajada. Alza los brazos y los tiende hacia mí. 


\section{O vazio}

Socorro Venegas

A Antonio Ramos Revillas

Dirijo os meus passos até o quarto do bebê. Não consigo chamá-lo de "filho". A porta se abre suavemente, a luz tênue de um abajur ilumina o berço. Ao lado, num futon, o pai dorme exausto. É uma imagem desoladora. Onde está a mãe dessas duas criaturas? Levo minhas mãos ao ventre: um vazio, ali onde o pequeno cresceu até o dia do nascimento. Sim, o fantasma da dor que não me deixa dormir.

Na noite mais profunda, a noite do insone, me levanto para andar pela casa. Pareço sonâmbula, mas sei que não sou. Olho para os cantos da casa e sinto vontade de chorar. Não sei explicar por quê.

Procuro, procurei entre as minhas mãos, as surpresas que saem da cartola do mágico. Nada.

Minha fé muda de lugar. Minha bússola errante, essa fé pequena.

Acordei com seu choro desconsolado, fui vê-lo e fiquei parada com os braços apoiados na grade do berço, observei com atenção seus traços, tão indefinidos, o que o fazia meu?, qual indiscutível semelhança? Senti o impulso de pegá-lo, mas não teria sido um gesto genuíno, senão um arrebato, um ato ditado pela impaciência, mais pelo cansaço de escutar os berros do que um ato de amor. Então ele chegou e como eu não fazia nada para consolar a criança me chamou de "monstro".

Estou sozinha nesta incompreensível espera por um ato de amor. Meu. Enquanto o menino chorava, o pai, com olhar inflamado, o tirou do berço. Era tão pequeno que podia segurá-lo com apenas um braço, com o outro me empurrou.

Eu não queria pari-lo. Gostava de sentir como se movimentava, um contorcionista sem limites. Sonhava que gestava um navegante, um marinheiro de abismos. Costumava me sentar para contemplar o jardim e ele entendia aquele momento de paz, ficava quieto para tornar-se apenas uma vibração, um pressentimento. Cheguei a acreditar que seria assim para sempre. É por isso que não entendo o que aconteceu? A agitação do hospital, o parto, as visitas, as flores.

$\mathrm{O}$ vazio que me tornei.

O leite ainda escapa dos meus seios, o esgoto e jogo na pia. "Não serve", lembro a ele quando me lança seu olhar de crítica. Tento me desculpar por ser um vazio desnecessário nesta nova vida que ele já organizou: prepara mamadeiras, troca fraldas, dá banho no bebê. Ocupa-se por inteiro. Não imaginava que as coisas seriam assim. "Para de olhar, 
você só sabe fazer isso, olhar!", grita, enquanto esconde entre os braços o pequeno corpo da minha angústia, aquele menino. Sou uma estranha na própria casa.

As únicas coisas que a desconhecida consegue fazer sozinha é se limpar e esgotar o leite, um líquido venenoso. O médico disse depois que o menino vomitou várias vezes: "Seu leite não é bom para o bebê". Deu a notícia enquanto a enfermeira se esforçava para que a criança pegasse o meu peito. Subitamente liberada, afastei-o de mim e virei para o outro lado da cama. Dormi.

O pai não permite que eu me aproxime para olhá-los. Este lado da casa já é terreno hostil. Temos uma empregada que traz a comida três vezes por dia até o meu quarto. Comida de doente: coisas pastosas, sem cor. Devem ter contado a ela alguma mentira para justificar o meu comportamento. Desconfio que colocam alguma coisa na comida, porque depois de comer, embora não de imediato, caio num sono profundo. Enquanto vou apagando, percebo como os familiares passam na frente da minha porta, escuto como cumprimentam o pai, brincam com o menino, entregam presentes, conversam sobre o meu "estado". "Medidas necessárias, obrigá-la...".

Às vezes não como e, pela janela, posso vê-los se afastando, olham de canto, sabem que estou aqui, me evitam. Conversam entre si. Disseram alguma coisa, decidiram alguma coisa. Me deito de novo, fecho os olhos, quero fazer de conta que estou dormindo, para enganar a quem? O fingimento traz um efeito inesperado, chega a letargia e, depois, o sono.

Não sei por quanto tempo dormi. Desta vez acordo com a risada do menino. Tenho dificuldade para reconhecer as paredes, o teto, a casa. Fico imóvel na cama durante um tempo. É um barulho encantador. Continua rindo. Mas uma criança tão pequena consegue rir desse jeito? Ponho os pés no chão frio e sinto cócegas que me fazem sorrir. Talvez um sorriso gélido, mas autêntico. Saio do quarto intrigada, a risada continua. Sigo o rastro dessa fortuna.

A casa parece deserta. Não vejo a empregada, sempre a postos e me vigiando. $\mathrm{O}$ menino está no meio da sala, sozinho, sentado em um tapete branco; se lambuza com um hidratante. Os braços e as pernas estão brancos. Uma vertigem me visita, me encosto na parede. Quanto tempo passou? Já consegue se sentar sem ser vencido pelo peso do seu corpo. Cresceu. Também está sozinho. Dá mais uma risada e, na sua brincadeira, dirige o olhar para onde estou. Vejo um dente nascendo naquela gargalhada. Levanta os braços e os estende para mim.

\section{Referência bibliográfica}

VENEGAS, Socorro. La memoria donde ardía. Madri: Páginas de Espuma, 2019. 